\title{
Mejora del resultado de las nuevas empresas internacionales a través de las redes empresariales y su influencia en la elección de modos de entrada cooperativos
}

\author{
María Ripollés ${ }^{1}$, Andreu Blesa \\ Universitat Jaume I, España
}

doi: $10.20420 /$ eni.2020.365

\begin{abstract}
Resumen
El artículo presenta los resultados de analizar la influencia de las redes empresariales de carácter social en la elección de modos de entrada cooperativos que no requieren inversión en capital (tales como la exportación indirecta). El ámbito de estudio son las empresas que se internacionalizan inmediatamente después de su creación o nuevas empresas internacionales. Se adopta una perspectiva amplia de la red empresarial que comprende los contactos de una empresa con otras generados en un contexto social cuyos beneficios se manifiestan a través del capital social. Concretamente, se argumenta que las ventajas informativas y conocimientos experienciales derivados del capital social son aspectos importantes para reducir los problemas asociados a la elección de dichos modos de entrada, aún incluso cuando los socios de los modos de entrada no provienen necesariamente de sus redes empresariales. Dado que el capital social depende de las acciones que se lleven a cabo para construirlas y mantenerlas, los empresarios de estas empresas deben establecer rutinas informales que permitan desarrollar actividades en coordinación con los miembros de su red.
\end{abstract}

Palabras clave: modo de entrada, resultados, red empresarial.

Clasificación JEL: L260, M130.

Fuente de referencia: Ripollés, M., \& Blesa, A. (2020). And yet, non-equity cooperative entries do improve international performance: uncovering the role of networks' social capital. Small Business Economics, 55, 761-776. Doi: 10.1007/s11187019-00186-1

\section{Introducción}

Los modos de entrada cooperativos sin inversión en capital (NCEM por el inglés nonequity cooperative entry modes), tales como la cesión de la marca, la subcontratación de la comercialización, la exportación indirecta o las franquicias de distribución, son los más adecuados para las nuevas empresas de rápida internacionalización (Berg y otros, 2008). Sin embargo, estos métodos pueden conllevar importantes problemas relacionados con la protección del posible riesgo de diseminación de la propuesta de valor para estas empresas, también conocidas como nuevas empresas internacionales (INV por el inglés international new ventures) (Paul y otros, 2017), lo que sugiere la consideración de las redes empresariales de carácter social entre empresas (en adelante redes), y del capital social generado en las mismas, como principal sistema de protección. Entendida de una forma amplia, la red de una empresa está formada por el conjunto de contactos directos, diádicos, informales, de carácter social y las relaciones entre estos contactos, con la empresa en el centro de la red. El capital social recoge los beneficios que las empresas pueden extraer de su actividad en una red, derivados de la confianza y de la colaboración voluntaria entre los miembros de la misma (Afandi y otros, 2017). Esta colaboración voluntaria aceptada por todos los miembros de la red se concreta en distintas dinámicas de interacción o normas relacionales que dan a los emprendedores una dirección precisa para sistematizar las relaciones dentro de las redes y generar un entorno viable en el que se produce su capital social (NSC por el inglés network social capital) (Adler \& Kwon, 2002).

${ }^{1}$ Autor de correspondencia: maria.ripolles@uji.es 
Este artículo presenta los resultados del estudio de Ripollés y Blesa (2020) sobre la importancia de las redes y, más concretamente, de la participación informal de la empresa en el intercambio de información y la coordinación interempresarial. La investigación adoptó una perspectiva instrumental para proporcionar una explicación más precisa de cómo se crea el NSC. Los resultados ponen de manifiesto que el capital social de las redes dota a las INV con ventajas informativas y conocimiento experiencial que es relevante para atenuar los problemas vinculados a la elección de NCEM, como pueden ser el posible desarrollo de un comportamiento oportunista por parte de los socios con los que se establece el NCEM, el riesgo de diseminación de la propuesta de valor y de los activos clave de las INV o la existencia de posibles conflictos entre los socios del acuerdo cooperativo.

\section{Redes empresariales de carácter social y capital social}

Las redes pueden definirse como el conjunto de vínculos sociales y las relaciones entre estos vínculos de una empresa. Los vínculos sociales o informales hacen referencia a las relaciones tácitas y particulares que no se establecen siguiendo ningún tipo de acuerdo legal (Rank, 2008). Como consecuencia, las relaciones entre los miembros de estas redes son informales y basadas en el compromiso voluntario (Afandi y otros, 2017), con el objetivo de lograr beneficios comunes.

Estas redes son relevantes para la rápida entrada y el crecimiento internacional de las INV. Pueden ayudar a estas empresas a percibir oportunidades, obtener recursos, aumentar la legitimidad y lograr otras estrategias y resultados ventajosos (Jones y otros, 2011), como la flexibilidad organizativa (Yousaf \& Majid, 2018). La principal idea que subyace es que la participación en estas redes puede contribuir a mejorar los resultados de las INV, fundamentalmente a través del uso del capital social en distintas estrategias empresariales
(Nahapiet \& Ghoshal, 1998). El capital social se define como los beneficios que una empresa puede obtener de una red, derivados de su participación activa y compromiso con la red (Afandi y otros, 2017). Cuando esta participación se concreta en dinámicas de interacción, como el intercambio de información y la coordinación interorganizacional, se incrementa el capital social y los beneficios que las empresas pueden obtener de su red. El ejercicio de dinámicas de interacción genera confianza, indulgencia y relaciones recíprocas entre los miembros de la red (Adler \& Kwon, 2002) que son la clave para que en las redes germine el capital social que puede ser utilizado como soporte distintas estrategias empresariales, como el establecimiento de NCEM (Berg y otros, 2008).

\section{Formas de entrada sin inversión en capital y resultados de las INV}

Este apartado recoge los hallazgos y conclusiones de la investigación desarrollada por Ripollés y Blesa (2020) en una muestra de 200 INV españolas que operaban en varios sectores. La investigación parte de la base de que la elección del modo de entrada afecta al resultado de las INV porque requiere inversión de recursos en varios mercados, cada uno de ellos con distintos niveles de riesgo, control y rentabilidad (Cannabal y otros, 2008). Las INV adoptan una amplia diversidad de modos de entrada, que incluyen tanto inversión directa como acuerdos formales de cooperación, que pueden implicar o no inversión en capital (Ripollés y otros, 2012). Entre los primeros se encuentran la creación de filiales o la adquisición de una empresa ya existente en el nuevo mercado. Entre los modos de entrada cooperativos que implican inversión se podría mencionar la adquisición de una participación de capital suficiente para controlar una empresa o la creación de una empresa participada conjuntamente. Entre los últimos, que son a los que nos referimos en este trabajo, estarían los ya mencionados acuerdos de cesión de marca, la subcontratación de una empresa del nuevo mercado para la comercialización, la 
exportación indirecta o la franquicia. Los distintos modos de entrada están relacionados con posibles beneficios y riesgos. Los modos de entrada que implican inversión en capital, sean o no cooperativos, pueden, por ejemplo, conseguir una mejor información del mercado y una mejor estrategia de distribución, pero también pueden verse afectados por barreras gubernamentales e implicar elevados riesgos organizativos. Por su parte, los modos cooperativos sin inversión en capital evitan los problemas relacionados con posibles restricciones financieras, pero cuentan con el potencial problema de encontrar socios fiables (Paul y otros, 2017). Sin embargo, los acuerdos formales sin inversión en capital con empresas extranjeras parecen ser los modos de entrada favoritos de las INV porque requieren de menos recursos, permiten una mayor flexibilidad $\mathrm{y}$ pueden ayudar a estas empresas a complementar sus capacidades estratégicas (Jones y otros, 2011). La exigencia de recursos, además de la ausencia de conocimientos específicos del mercado extranjero y la reducida legitimidad en dicho mercado, son las principales razones que explican la influencia de los modos de entrada sin inversión en capital en los resultados de las INV (Ripollés \& Blesa, 2020).

\section{El papel de las dinámicas de interacción}

Tal y como hemos señalado las INV pueden obtener varias ventajas al elegir modos de entrada cooperativos que no requieran inversión en capital, como conseguir recursos para el desarrollo de una ventaja competitiva en los mercados internacionales. Sin embargo, las modalidades de entrada sin inversión en capital también pueden aumentar el riesgo de pérdidas debido a un comportamiento oportunista de los socios (Berg y otros, 2008). Aunque las INV pueden prever el comportamiento oportunista de futuros socios, no les resulta fácil protegerse mediante patentes $\mathrm{u}$ otros medios legales (Williamson, 1985), ya que su frágil capacidad de negociación limita el éxito de esas herramientas (Berg y otros, 2008).
Una relación de colaboración sin inversión en capital puede ser un modo de entrada eficiente, pero también entraña importantes riesgos para las INV. Por ejemplo, mientras que los NCEM permiten el acceso a los mercados, las INV, a cambio, ceden algo de control, lo que las obliga a confiar en la buena voluntad de sus socios. Sin embargo, dado que las INV no tienen contacto directo con sus mercados internacionales, la información proporcionada por los intermediarios puede estar filtrada, lo que compromete la base de conocimiento de las INV. Esto hace especialmente relevante el coste de mantener una relación, lo que resalta la importancia del capital social -generado a partir de las dinámicas de interacción- como instrumento para protegerse de los posibles riesgos asociados a los NCEM.

El papel de la actividad de intercambio de información en la red

Las INV necesitan información sobre posibles socios extranjeros y sobre su idoneidad. Además, los posibles socios deben tener la certeza de que trabajar con las INV dará lugar a beneficios mutuos, a pesar de la ausencia de legitimidad de las INV (Berg y otros, 2008). El compromiso de los miembros de la red de compartir información entre sí puede ser una fuente fiable. El intercambio de información reduce el oportunismo al hacer más probable que se identifique tal comportamiento y que la información se expanda rápidamente a través de la red. Debido a que la creación de reputación lleva tiempo y puede destruirse con facilidad, el intercambio de información entre los miembros de la red puede ayudar a desincentivar un comportamiento oportunista (Gulati, 1998).

Las INV identifican dos fuentes para encontrar socios que permitan la entrada en nuevos mercados internacionales: que los socios de NCEM formen parte de la red actual de la empresa y que los socios de NCEM no formen parte de la misma (Ripollés \& Blesa, 2017). En 
ambos casos, el compromiso de los miembros de la red social por compartir información ofrece acceso y referencias, lo que reduce la probabilidad de enfrentarse a futuros comportamientos oportunistas de los socios de NCEM. En la primera situación, el intercambio de información proporciona a las INV evidencias sobre la capacidad y la idoneidad de los miembros de sus redes para establecer contratos de cooperación sin inversión en capital. A través de este intercambio de información, las INV tienen la oportunidad de evaluar las intenciones y motivaciones de los miembros de su red de manera adecuada. Con respecto a la segunda de las situaciones, las INV buscan entre los miembros de la red orientación y asistencia cuando piensan en seleccionar nuevos socios con los que establecer NCEM para entrar en nuevos mercados extranjeros. A través de los miembros de su red, las INV pueden obtener información específica sobre las habilidades y el comportamiento probable de un posible socio que no es miembro de la red actual de las INV con el que establecer NCEM. Además, las INV pueden comunicar a los miembros de sus redes cualquier comportamiento no apropiado de los socios con los que han establecido NCEM a través de la actividad de intercambio de información, lo que disminuye el riesgo de oportunismo de los socios de NCEM (Gulati, 1998). Mediante la actividad de intercambio de información entre los miembros de la red, se asegura el buen comportamiento de los socios de NCEM con el interés en mantener su reputación. De hecho, un aumento en el grado de intercambio de información supone una influencia positiva de los modos de entrada cooperativos sin inversión de capital en los resultados de las INV (Ripolles \& Blesa, 2020).

\section{El papel de la coordinación interorganizacional}

Dado que los miembros de la red pueden enfrentarse a inconvenientes debido a un comportamiento oportunista inesperado, recurren a reglas implícitas de cooperación para mejorar la relación entre ellos. A través de la implicación de los miembros de la red en la coordinación interorganizacional, las empresas tienen la posibilidad de evaluar los objetivos, motivaciones y habilidades cooperativas de otros miembros, así como su propia capacidad de cooperación (Ripollés \& Blesa, 2017). Esta participación genera una base para prever el comportamiento de socios futuros y facilita la elaboración de hipótesis sobre su cumplimiento de las reglas de los acuerdos de colaboración sin inversión en capital (Dyer \& Singh, 1998).

Además, cuando un socio no procede de las redes de las INV, las empresas no cuentan con información previa que les permita trazar las etapas con las que cumplir los objetivos de los modos de entrada cooperativos sin inversión en capital. Sin experiencia previa, las INV perciben $\mathrm{su}$ participación en la coordinación interorganizacional de los socios de la red como una experiencia que puede ayudarles a identificar los límites funcionales permitidos en nuevos acuerdos de colaboración (Dyer \& Singh, 1998). Por lo tanto, la coordinación entre los miembros de la red ayuda a las INV a liderar los MCEM, incluso si los socios no proceden de sus redes. En consecuencia, existe un alto efecto NCEM en el resultado de las INV cuando el grado de coordinación interorganizacional entre los miembros de la red social es alto (Ripollés \& Blesa, 2020).

\section{Conclusiones}

La investigación de Ripollés y Blesa (2020) ha demostrado que las INV pueden usar sus redes al elegir modos de entrada cooperativos sin inversión en capital, y que el NSC tiene un efecto positivo en la relación entre los NCEM y el resultado internacional de las INV. Dicha investigación ha establecido un vínculo positivo entre los modos de entrada cooperativos sin inversión en capital y los resultados de las INV, destacando la necesidad de pensar en la importancia del NSC como un componente que contribuye a mejorar los resultados. 
Los resultados de Ripollés y Blesa (2020) muestran, además, que las consecuencias negativas para las INV de la elección de NCEM se pueden atenuar o eliminar sustancialmente con una gestión de las relaciones que contribuya a mejorar su capital social. En este sentido es especialmente relevante para las INV no solo involucrarse en redes, ya sean cohesionadas o dispersas, sino conseguir que los integrantes de esa red se involucren en la creación de capital social. Para ello, las INV deberían identificar los miembros de la red dispuestos a intercambiar información e implicarse en el establecimiento informal de actividades de coordinación interorganizacional, ya que el desarrollo de estas actividades les ayudará a aprovechar ventajas intangibles relacionadas con su participación en las redes, como son las ventajas informativas y la experiencia relacional. Adicionalmente, estos beneficios pueden transferirse fácilmente a la cooperación formal, como el desarrollo de modos de entrada cooperativos sin inversión en capital.

Por tanto, los emprendedores de las INV harían bien en involucrarse en la compleja labor de implementar actividades relacionales con los miembros de su red especialmente, si cabe, en este momento, caracterizado por los efectos de la crisis global de la Covid-19. Está claro que la Covid-19 ya ha provocado importantes cambios en el entorno empresarial que afectarán profundamente a las INV en los próximos años (Zahra, 2020). Entre ellos Zahra (2020) sugiere que, en muchos casos, las redes de las INV sufrirán importantes cambios e incluso desaparecerán, lo cual impactará de manera significativa en la actividad de las INV. La interrupción de la actividad en las redes existentes probablemente esté obligando a las INV a reconstruirlas (Zahra, 2020), por lo que las INV deberían considerar como redes potencialmente atractivas aquellas en las que sus participantes estén dispuestos a comprometerse con el intercambio de información y a coordinarse entre ellos sin la necesidad de que exista un acuerdo formal que regule dicha colaboración. Además, si la INV ya participa de redes comprometidas con estas dinámicas de interacción ha adquirido experiencia relacional, lo que le ayudará a evaluar y predecir el potencial de los futuros miembros de la red y saber identificar a quiénes estén dispuestos a cooperar e iniciar nuevas relaciones sociales. Por lo tanto, el desarrollo de estas dinámicas de interacción puede ser un factor clave para que las INV recuperen sus resultados positivos en la era posCovid.

\section{Referencias}

Afandi, E., Kermani, M., \& Mammadov, F. (2017). Social capital and entrepreneurial process. International Entrepreneurship and Management Journal, 13(3), 685-716. Doi: 10.1007/s11365-0160421-8.

Adler, P.S., \& Kown, S.-W. (2002). Social Capital: Prospects for a New Concept. Academy of Management Review, 27(1), 17-40. Doi: 10.5465/amr.2002.5922314.

Berg, M.S., Aspelund, A., \& Sørheim, R. (2008). The Hybrid Structures of International New Ventures. A Social Capital Approach and Research Agenda. Journal of Entrepreneurship and Innovation, 9(1), 33-42. Doi: 10.5367/000000008783562993.

Dyer, J.H., \& Singh, H. (1998). The Relational View: Cooperative Strategy and Sources of Interorganizational Competitive Advantage. Academy Management Review, 23(4), 660-679. Doi: 10.2307/259056.

Gulati, R. (1998). Alliances and Networks. Strategic Management Journal, 19, 293-317. Doi: 10.1002/(SICI)1097-0266(199804)19:4<293:AIDSMJ982>3.0.CO;2-M.

Jones, M.V., Coviello, M., \& Tang, Y.K. (2011). Entrepreneurship Research (1989-2009): A Domain Ontology Analysis. Journal of Business Venturing, 26, 632-659. Doi: 10.1016/j.jbusvent.2011.04.001.

Nahapiet, J., \& Ghoshal, S. (1998). Social capital, intellectual capital, and the organizational advantage. Academy of Management Review, 23(2), 242-266. Doi: 10.5465/amr.1998.533225.

Paul, J., Parthasarathy, S., \& Gupta, P. (2017). Exporting challenges of SMEs: A review and future research agenda. Journal of World Business, 52, 327342. Doi: 10.1016/j.jwb.2017.01.003.

Rank, O.N. (2008). Formal structures and informal networks: Structural analysis in organizations. 
Scandinavian Journal of Management, 24(2), 145161. Doi: 10.1016/j.scaman.2008.02.005.

Ripollés, M., Blesa, A., \& Monferrer, D. (2012). Factors enhancing the choice of higher resource commitment entry modes in international new ventures. International Business Review, 21(4), 648666. Doi: 10.1016/j.ibusrev.2011.07.007.

Ripollés, M., \& Blesa, A. (2017). Entry mode choices in the international new ventures context. A study from different theoretical perspectives. International Entrepreneurship and Management Journal, 13(2), 465-485. Doi: 10.1007/s11365-016-0410-y.

Ripollés, M., \& Blesa, A. (2020). And yet, non-equity cooperative entries do improve international performance: uncovering the role of networks' social capital. Small Business Economics, 55, 761-776. Doi: 10.1007/s11187-019-00186-1
Williamson, O.E. (1985). The economic institutions of capitalism. New York: The Free Press.

Woodcock, C.P., Beamish, P.W., Makino, S. (1994). Ownership-based entry mode strategies and international performance. Journal of International Business Studies, 25(2), 253-273. Doi: $10.1057 /$ palgrave.jibs. 8490200 .

Yousaf, Z., \& Majid, A. (2018). Organizational network and strategic business performance: Does organizational flexibility and entrepreneurial orientation really matter? Journal of Organizational Change Management, 31(2), 268-285. Doi: 10.1108/JOCM-12-2016-0298.

Zahra, S.A. (2020). International entrepreneurship in the post Covid world. Journal of World Business, 101143 . 


\title{
Improving the performance of new international companies through business networks and their influence on the choice of non-equity cooperative entry modes
}

\author{
María Ripollés ${ }^{1}$, Andreu Blesa
}

Universitat Jaume I, Spain

\begin{abstract}
The article presents the results of analysing the influence of business networks of a social nature in the choice of cooperative entry modes that do not require capital investment (such as indirect export). The scope of study are companies that go international immediately after their creation or new international companies. A broad perspective of the business network is adopted that includes the contacts of a company with others generated in a social context whose benefits are manifested through social capital. Specifically, it is argued that the informational advantages and experiential knowledge derived from social capital are important aspects to reduce the problems associated with the choice of those entry modes, even when the partners of the entry modes do not necessarily come from their business networks. Since social capital depends on the actions that are carried out to build and maintain business networks, the entrepreneurs of these companies must establish informal routines that allow them to develop activities in coordination with the members of their network.
\end{abstract}

Keywords: Entry mode, performance, business network.

JEL classification: L260, M130.

Reference source: Ripollés, M., \& Blesa, A. (2020). And yet, non-equity cooperative entries do improve international performance: uncovering the role of networks' social capital. Small Business Economics, 55, 761-776. Doi: 10.1007/s11187019-00186-1

\section{Introduction}

Non-equity cooperative entry modes (NCEM), such as brand transfer, marketing outsourcing, indirect export, or distribution franchises are the most suitable entry modes for rapid internationalization companies (Berg and others, 2008). However, these methods can lead to important problems related to the protection of the possible risk of dissemination of the value proposition for these companies, also known as international new ventures (INV) (Paul and others, 2017), which suggests the consideration of business networks of a social nature between companies (hereinafter networks), and the social capital generated in them, as the main protection system. Broadly understood, the network of a company is formed by the set of direct, dyadic, informal, social contacts and the relationships between these contacts, with the company at the centre of the network. Social capital collects the benefits that companies can extract from their activity in a network, derived from trust and voluntary collaboration among its members (Afandi and others, 2017). This voluntary collaboration accepted by all members of the network is specified in different interaction dynamics or relational norms that give entrepreneurs a precise direction for systematizing relationships inside social networks and generating a workable environment in which networks' social capital (NSC) occurs (Adler \& Kwon 2002).

This paper presents the results of Ripollés and Blesa's (2020) study of the importance of network and, more specifically, of the informal involvement of the company in information interchange and inter-firm coordination. The research took an instrumental approach to provide a more precise explanation of how NSC is created. The results show that networks' social

${ }^{1}$ Corresponding author: maria.ripolles@uji.es 
capital endows INVs with informational advantages and experiential knowledge that plays a significant role in lessening the issues linked to the choice of non-equity entry modes, such as the possible development of opportunistic behaviour by the partners. with which the NCEM is established, the risk of dissemination of the value proposition and the key assets of the INV or the existence of possible conflicts between the partners of the cooperative agreement.

\section{Business networks of a social nature and social capital}

Social networks can be defined as the set of informal ties and the relationships among these ties. Informal ties are tacit and particular relationships not set up in agreement with any sort of legal accord (Rank 2008). As a consequence, relationships among the members of these networks are informal and based on personal engagement (Afandi and others, 2017), with the aim of achieving common benefits.

These networks are relevant for INVs' quick international entry and growth. They can help these companies to perceive opportunities, obtain resources, increase legitimacy and attain other advantageous strategies and results (Jones and others, 2011), such as organizational flexibility (Yousaf \& Majid, 2018). The main intuition underlying is that participation in networks can contribute to improving results mostly through the social capital that is generated among the members of the network. Social capital is defined as the benefits that a company can obtain from a network derived from its active participation and commitment to the network (Afandi and others, 2017). When this participation takes the form of interaction dynamics such as the exchange of information and interorganizational coordination, the social capital and the benefits that companies can obtain from their network increase. The exercise of interaction dynamics generates trust, indulgence and reciprocal relationships among partners (Adler \& Kwon 2002), which are the key for social capital to germinate in networks that can be used as support for different business strategies (Nahapiet \& Ghoshal 1998) and the NCEM establishment (Berg and others, 2008).

\section{Non-equity cooperative entry modes and INVs' international performance}

This section collects the findings and conclusions of the research carried out by Ripollés and Blesa (2020) in a sample of 200 Spanish INVs that operated in several sectors. The research starts from the basis that the choice of entry mode affects INVs' international performance because it requires the investment of resources in various markets, each of them with dissimilar levels of risk, control and returns (Cannabal and others, 2008). INVs take a wide variety of entry modes, including both equity and non-equity (Ripollés and others, 2012). Among the former are the creation of subsidiaries or the acquisition of an existing company in the new market. Cooperative entry modes that involve investment could include the acquisition of a sufficient equity stake to control a company or the creation of a jointly owned company. Among the latter, which are the ones we refer to in this work, would be the aforementioned brand transfer agreements, the subcontracting of a company in the new market for marketing, indirect exports or franchising. Both modes are connected to potential profits and dangers. Modes of entry that involve capital investment, whether cooperative or not, can, for example, lead to a better market information and a better distribution strategy, but they can also be affected by government barriers and involve high organizational risks. On the other side, cooperative modes without capital investment avoid the problems related to eventual financial constraints, but have the potential problem of finding reliable partners (Paul and others, 2017). Nevertheless, non-equity formal relations with foreign firms appear to be INVs' favourite entry 
modes because they are less intense in assets, allow for greater flexibility and can help these companies to supplement their strategic abilities (Jones and others, 2011). The demand for resources, absence of foreign know-how and restricted market legitimacy are the main reasons explaining the influence of NCEM on INVs' international performance (Ripollés \& Blesa 2020).

\section{The role of interaction dynamics}

INVs can obtain several advantages from choosing NCEM, such as resource investment and the development of a competitive advantage in international markets. NCEM, nevertheless, may also increase the danger of losses arising from opportunistic behaviour carried out by partners (Berg and others, 2008). Although INVs could expect opportunistic behaviour from future partners, it is not easy to protect themselves by copyrights or other legal means (Williamson 1985), as their fragile capability to negotiate would restrict the success of those tools (Berg and others, 2008).

A non-equity collaborative relationship should be cultured and sustained, although INVs might face relevant risks when it occurs. For example, while NCEM allow access to markets, INVs in return give up some control, which obliges them to trust their partners' goodwill. Nevertheless, since international new ventures have no direct contact with their foreign markets, the information provided by middlemen may be filtered, which compromises the INVs' knowledge base. This makes the cost of maintaining a relationship especially relevant, which highlights the importance of social capital -generated from interaction dynamics- as an instrument to protect against the possible risks associated with NCEMs.
The moderating role of network information exchange activity

INVs require information on possible nonequity cooperative foreign partners and on their appropriateness. Moreover, possible partners must be certain that working together will give rise to mutual benefits, even with the notable limitation of INVs' absence of market legitimacy (Berg and others, 2008). The commitment of the members of the social network to share information with one another can be a reliable source. Information exchange reduces opportunism by making it more likely that such behaviour will be identified and that the information will expand rapidly throughout the social network. Because reputation takes time to create but can be destroyed with ease, information sharing among networked members can generate strong deterrents for opportunistic behaviour (Gulati 1998).

INVs identify two sources to find partners that allow entry into new international markets: NCEM partners will be part of the company's social network and they will not be part of it (Ripollés \& Blesa, 2017). In both cases, the commitment of the members of the social network to sharing information offers access, timing and referrals, which lowers the probability of facing opportunistic behaviours by NCEM partners. In the first situation, information exchange supplies INVs with information on the capacity and appropriateness of the members of their networks to set up nonequity cooperative contracts. Through this information sharing, INVs have a chance to evaluate their partners' intentions and motivations in an appropriate way. Regarding the second of these situations, INVs look to their network partners in search of guidance and assistance when thinking of selecting new nonequity cooperative partners to go into foreign markets. Through their network partners, INVs can obtain specific information about the abilities and probable behaviour of a possible NCEM 
partner, who is not a member of the INVs' social network. Besides, INVs can communicate any inappropriate behaviour by any NCEM partner to their network partners through information sharing activity, which serves as a restriction for both and lessens the danger of opportunism (Gulati 1998). Through information exchange among the members of the network a reputational lock-in could be generated by which good behaviour by non-equity cooperative partners is ensured through an interest in keeping up their local image. In fact, a rise in the degree of information interchange increases the positive influence of NCEM on INVs' international performance (Ripollés \& Blesa, 2020).

\section{The moderating role of inter-organizational coordination.}

Since network partners may encounter drawbacks due to unexpected opportunistic behaviour, the members of a network turn to implicit rules of social cooperation to increase solidarity among the network partners. Through the commitment of network members to interorganizational coordination, companies have a chance to evaluate their network members' aims, motivations and cooperative abilities. They can also assess their own ability to cooperate and know what behaviour is adequate when embracing cooperative plans (Ripollés \& Blesa, 2017). This relational involvement generates a basis for foresights about future partners' behaviour and makes it easier to draw conjectures about their compliance with the rules of non-equity collaborative accords (Dyer \& Singh, 1998).

Additionally, when an NCEM partner does not belong to INVs' networks, companies do not have any previous information allowing them to trace the stages with which the aims of NCEM are fulfilled. With no prior experience, INVs perceive their involvement in interorganizational coordination among their network partners as a practical experience that can help them to identify the functional limits that are permitted in new collaborative agreements (Dyer \& Singh, 1998). Thus, inter-organization coordination among network partners helps INVs to lead MCEMs, even though the members do not come from their networks. Consequently, there is a high effect of NCEM on INVs' international performance when the degree of inter-organizational coordination is high (Ripollés \& Blesa, 2020).

\section{Conclusions}

Ripollés and Blesa's (2020) research has shown that INVs can use their networks when choosing NCEM, and that NSC plays a positive effect on the relationship between NCEM and INVs' international performance. That research has established a positive link between NCEM and INVs' international performance and highlights the need to think about the relevance of NSC as a component that contributes to improving results.

Ripollés and Blesa's (2020) results showed that the negative consequences of choosing NCEM for INVs can be substantially lessened or removed with a management of social relationships that contributes to raising the INVs' social capital. The relevant point is that not only is it important to get involved in cohesive or dispersed networks, but that the members of that social network will be actively involved in creating social capital. For this, the INV should identify the members of the network willing to exchange information and get involved in the informal establishment of interorganizational coordination activities, since the development of these activities will help them to take advantage of intangible benefits related to their participation in the networks such as informational advantages and relational experience. These benefits can be easily transferrable to formal cooperation, such as the development of NCEM. 
Therefore, INV entrepreneurs would do well to get involved in the complex task of implementing relational activities with the members of their network, especially, if possible, at this time, characterized by the effects of the global COVID crisis. COVID has already caused major changes in business environment which will profoundly affect INVs in the years to come (Zahra 2020). the interruption of activity in existing networks is probably forcing INVs to rebuild them (Zahra 2020), so INV should consider as potentially attractive networks those in which their participants are willing to commit to the exchange of information and coordinate between them without the need for a formal agreement to regulate said collaboration.

In addition, if the INV already participates in networks committed to these interaction dynamics, it has acquired relational experience, which will help it assess and predict the potential of future members of the network and know how to identify those who are willing to cooperate and to initiate new relationships. social. Therefore, the development of these interaction dynamics is called to be a determining factor for INVs to recover their positive results in the post-COVID era.

\section{Referencias}

Afandi, E., Kermani, M., \& Mammadov, F. (2017). Social capital and entrepreneurial process. International Entrepreneurship and Management Journal, 13(3), 685-716. Doi: 10.1007/s11365-0160421-8.

Adler, P.S., \& Kown, S.-W. (2002). Social Capital: Prospects for a New Concept. Academy of Management Review, 27(1), 17-40. Doi: 10.5465/amr.2002.5922314.

Berg, M.S., Aspelund, A., \& Sørheim, R. (2008). The Hybrid Structures of International New Ventures. A Social Capital Approach and Research Agenda. Journal of Entrepreneurship and Innovation, 9(1), 33-42. Doi: 10.5367/0000000008783562993.

Dyer, J.H., \& Singh, H. (1998). The Relational View: Cooperative Strategy and Sources of Interorganizational Competitive Advantage. Academy Management Review, 23(4), 660-679. Doi: 10.2307/259056.
Gulati, R. (1998). Alliances and Networks. Strategic Management Journal, 19, 293-317. Doi: 10.1002/(SICI)1097-0266(199804)19:4<293:AIDSMJ982>3.0.CO;2-M.

Jones, M.V., Coviello, M., \& Tang, Y.K. (2011). Entrepreneurship Research (1989-2009): A Domain Ontology Analysis. Journal of Business Venturing, 26, 632-659. Doi: 10.1016/j.jbusvent.2011.04.001.

Nahapiet, J., \& Ghoshal, S. (1998). Social capital, intellectual capital, and the organizational advantage. Academy of Management Review, 23(2), 242-266. Doi: 10.5465/amr.1998.533225.

Paul, J., Parthasarathy, S., \& Gupta, P. (2017). Exporting challenges of SMEs: A review and future research agenda. Journal of World Business, 52, 327 342. Doi: 10.1016/j.jwb.2017.01.003.

Rank, O.N. (2008). Formal structures and informal networks: Structural analysis in organizations. Scandinavian Journal of Management, 24(2), 145161. Doi: 10.1016/j.scaman.2008.02.005.

Ripollés, M., Blesa, A., \& Monferrer, D. (2012). Factors enhancing the choice of higher resource commitment entry modes in international new ventures. International Business Review, 21(4), 648666. Doi: 10.1016/j.ibusrev.2011.07.007.

Ripollés, M., \& Blesa, A. (2017). Entry mode choices in the international new ventures context. A study from different theoretical perspectives. International Entrepreneurship and Management Journal, 13(2), 465-485. Doi: 10.1007/s11365-016-0410-y.

Ripollés, M., \& Blesa, A. (2020). And yet, non-equity cooperative entries do improve international performance: uncovering the role of networks' social capital. Small Business Economics, 55, 761-776. Doi: 10.1007/s11187-019-00186-1

Williamson, O.E. (1985). The economic institutions of capitalism. New York: The Free Press.

Woodcock, C.P., Beamish, P.W., Makino, S. (1994). Ownership-based entry mode strategies and international performance. Journal of International Business Studies, 25(2), 253-273. Doi: 10.1057/palgrave.jibs. 8490200 .

Yousaf, Z., \& Majid, A. (2018). Organizational network and strategic business performance: Does organizational flexibility and entrepreneurial orientation really matter? Journal of Organizational Change Management, 31(2), 268-285. Doi: 10.1108/JOCM-12-2016-0298.

Zahra, S.A. (2020). International entrepreneurship in the post Covid world. Journal of World Business, 101143. 